\title{
INFORMAL SOCIAL NETWORK AND TECHNICAL KNOWLEDGE TRANSFER IN R\&D
}

\author{
Lourdes Carniello Ribeiro \\ lourdescarniello@gmail.com \\ Universidade Federal Fluminense - RJ / Brasil \\ Martius Vicente Rodriguez Y Rodriguez \\ martius@kmpress.com.br \\ Universidade Federal Fluminense - RJ / Brasil
}

http://dx.doi.org/10.1590/1413-2311.02814.50197

Recebido em 12/09/2014

Aprovado em 31/05/2016

Disponibilizado em 31/01/2017

Avaliado pelo sistema "double blind review"

Revista Eletrônica de Administração

Editora-chefe: Aurora Zen

ISSN 1413-2311 (versão "on line")

Editada pela Escola de Administração da Universidade Federal do Rio Grande do Sul.

Periodicidade: Quadrimestral

Sistema requerido: Adobe Acrobat Reader

\section{REDE SOCIAL INFORMAL E TRANSFERENCIA DE CONHECIMENTO TÉCNICO EM P\&D}

\begin{abstract}
RESUMO
No mundo corporativo há um crescente interesse em Gestão de Conhecimento (CG). A capacidade das empresas de compilar o conhecimento acumulado, organizá-lo e torná-lo uma vantagem competitiva, é hoje o grande desafio das empresas modernas. Cada vez mais, as organizações são valoradas por aquilo que sabem. Conhecer a organização, sua cultura e como seus funcionários se relacionam formal ou informalmente, torna-se fundamental para a elaboração de estratégias para implantação de uma GC eficiente. O relacionamento formal é facilmente identificado nos organogramas de qualquer tipo de organização já os relacionamentos informais, que geram grande sinergia, são pouco explorados como forma de compartilhamento de conhecimento.

$\mathrm{O}$ presente artigo tem como objetivo apresentar como ocorre o relacionamento interpessoal numa gerência geral do CENPES (Centro de Pesquisas Leopoldo Américo Miguez de Mello) que desenvolve projetos de engenharia básica para a indústria do petróleo e gás, identificando seus principais atores através da técnica da Análise das Redes Sociais (ARS). Buscou-se revelar como a amostra de funcionários está organizada, levando-se em consideração quatro fatores de análise, a saber: informação, conhecimento, amizade e confiança. Para obtenção dos dados foi realizada uma pesquisa através de questionários aplicados aos funcionários da unidade estudada. Para as análises foram utilizadas as ferramentas UCINET e NETDRAW.
\end{abstract}


Como resultados foram identificados os principais atores dos quatro fatores de análise e qual o relacionamento entre o grupo. Verificou-se gargalo na transferência de informação e conhecimento bem como pouca interação entre as gerências estudadas.

Palavras-chave: Gestão do Conhecimento; Análise de Redes Sociais; Informação e Conhecimento.

\title{
INFORMAL SOCIAL NETWORK AND TECHNICAL KNOWLEDGE TRANSFER IN R\&D
}

\begin{abstract}
There's a growing interest in Knowledge Management (KM) in the corporate world. The company's ability to compile the accrued knowledge, organize are valued by what they know. Knowing the organization, its culture and how your employees relate themselves formal or informally, became fundamental for elaborating strategies for an efficient KM application. The formal relationship is easily recognized in the organizational charts of any organization type; however the informal relationships, which generate high synergy, are not much explored as a manner of knowledge sharing.

The present article has the purpose of presenting how the interpersonal relationship occurs in a general management of CENPES (Research Center Leopoldo Américo Miguez de Mello) which develops basic engineering projects for the oil and gas industry, identifying its key actors through the Social Network Analysis (SNA). We aimed to reveal how the employee sample is organized, considering four analysis factors: information, knowledge, friendship and trust. For data source, a survey was performed through questionnaires applied for the employees of the studied unit. For the analysis, UCINET and NETDRAW tools were used. As results, the key actors were identified for the four analysis factors and which is the relationship among the group. We have verified a bottleneck in information and knowledge transfer as well as little interaction among the groups of studied management teams.
\end{abstract}

Key words: Knowledge management; Social Network Analysis; Information and Knowledge.

\section{RED SOCIAL INFORMAL Y TRANFERENCIA DE CONOCIMIENTO TECNICO EN I+D}

\section{RESUMEN}

En el mundo corporativo hay un creciente interés por Gestión del Conocimiento (CG). La capacidad de las empresas de compilar el conocimiento acumulado, organizarlo y convertirlo en una ventaja competitiva es hoy el gran desafío de las empresas modernas. Cada vez más, las organizaciones son valoradas por lo que saben. Conocer la organización, su cultura y cómo sus empleados se relacionan formal e informalmente, se hace fundamental para la elaboración de estrategias para implementación de una CG eficiente. El relacionamiento formal es fácilmente identificado en los organigramas de cualquier tipo de organización, por 
otra parte los relacionamientos informales, los cuales generan gran sinergia, son poco explorados como forma de compartir el conocimiento.

El presente artículo objetiva presentar cómo ocurre el relacionamiento interpersonal en un gerencia general del CENPES (Centro de Pesquisas Leopoldo Américo Miguez de Mello), la cual desarrolla proyectos de ingeniería básica para la industria de petróleo y gas, identificando sus actores principales por intermedio de la técnica de análisis de las redes sociales (ARS). Se trató de revelar como la muestra de empleados está organizada, teniendo en cuenta cuatro factores de análisis, o sea: información, conocimiento, amistad y confianza. Para la obtención de los datos fue realizada una investigación por medio de encuestas aplicadas a los funcionarios de la unidad investigada. Para el análisis fueron utilizadas herramientas UCINET y NETDRAW. Como resultados se identificaron los actores principales de los cuatro factores de análisis y el relacionamiento entre los elementos del grupo. Se verificó un cuello de botella respecto a la transferencia de información y conocimiento, así como muy poca interacción entre las gerencias investigadas.

Palabras-clave: Gestión del Conocimiento; Análisis de las redes socials; Información y conocimiento.

\section{INTRODUCTION}

In the current global scenario of intense information exchange, several medias contribute for effectively optimize the communication, but certainly still are the people involved the main actors of any information system, they are the generating source of any message. Information and communication technologies (ICT) have made the information access easier and more democratic, collaborating for the elimination of barriers. The corporate world, which has obtained the most advantages with the ICT solutions implementation with the development of collaborative tools, created with the aim to improve the employees interactivity, yet always with the clear intention of improving the efficiency and obtaining competitive advantages. In modern organizations, the growing interest in knowledge management is based, according to Davenport and Prusak (1998), in knowing were the knowledge is, how to get to it and how to use it.

Information naturally circulates within organizations, today at a higher speed, and may generate knowledge and value. The employees' accrued knowledge is an intangible assets that is increasingly more valuable, but, to became visible and increase the business development, the organizations must develop strategies for sharing this knowledge, beginning with identifying information and knowledge generating sources and how knowledge spreading this sources are or may be. 
In conducting engineering projects, interaction between actors is stimulated by the necessity of data or input exchange, which generates a complex precedence network for activities to be executed. For Loiola and Moura (1997, p.55), when we talk about activities focused in the interaction between individuals, social networks come to share information, "aiming at communication, exchange and mutual help" within a common interest area.

The appearance of an Informal Social Network (ISN) in the organization occurs by the establishment of linkages between individuals, which Marteleto (2001) describes as structures formed by links.

In social networks, there's the appreciation of informal links and relationships, in detriment of hierarchical structures. Today, the informal work in networks is a way of human organization present in our daily life and in the most different structure levels of modern institutions. (MARTELETO, 2001, p.72).

In informal social networks (ISN) formed within organizations, people are always asking each other what people know to do, aiming at searching for guidance or instruction for developing activities. According to Davenport and Prusak (1998), this interaction, which is only possible among people, is capable of generating knowledge through received information processing, written documents or face to face contact, as conversations or learning relations.

The organization may not create knowledge by itself, without the individual initiative and the interaction that occurs within the group, according to Katzenbach and Smith (1993 apud CHINOWSKY, DIEKMANN, O'BRIEN, 2010, p.453) "the key to knowledge exchange is the level of trust among the team members".

SNA is a technique that favors the understanding of how is occurring the information exchange within organizations and how interpersonal relationships contribute or not for this information to flow within organizations.

According to Cross and Parker (2004), SNA also contributes for the understanding of how the work is actually executed with the purpose of obtaining the best employee performance and, consequently, the best organizational performance.

The company's concern, described in this article, of retaining the knowledge obtained from its employees is really significant. For belonging to a research center, this concern is amplified due to the high level of investment applied to work force to ensure the pioneering necessary for intellectual production. The loss of key individuals within this organizational structure may weaken an entire project, as well as a knowledge internalization process. 
Ensuring agility at the knowledge transfer with quality is a challenge for the high management.

Knowledge transfer involves individuals. This ability of the human being praises the existence of an information source individual who inspires trust and is available for providing it, and another individual, the receiver, who must be open for absorbing and accepting the new. According to Davenport and Prusak (1998), this exchange relation involves personal and psychological factors.

With SNA it is possible to detect how personal and social factors favor or not the knowledge exchange from the relationship between the actors.

The present article presents a case study that aimed at answering the following question: Which is the contribution of informal social networks for the technical knowledge transfer process at the $\mathrm{R} \& \mathrm{D}$ area?

The main objective is verify if there is a relation between informal social network and the ability to share technical knowledge among actors, which form a multidisciplinary and high specialized teams in $R \& D$ that develops basic engineering projects to oil and gas industry. To assist in achieving this objective were defined as specific objectives: mapping how information exchange occurs among actors at a basics engineering management; verifying the interaction standard among actors and discovering which actors, in the group formed by professional with senior level, mid-level and junior level, develop the information replicators and/or connector function in their respective operation areas; verifying if there are bottlenecks in information and knowledge transfer.

\section{LITERATURE REVIEW}

\subsection{Social network analysis}

The Social Network Analysis (SNA) occurs from the mapping and measurement of interpersonal relations. It concerns a mathematic model that analyses individual behaviors from relations existing between them. This analysis may be individual, applied to teams or organizations. The term SNA is inserted in the sociology area.

What we know about SNA was elaborated from 1930 in three major lines of thought, composed by Sociometry analysts, Researchers at Harvard University and Researchers of 
Manchester University, which performed several surveys conducted by the three lines at the same time. At several times the lines were aligned and lead to a common result.

SNA was developed in precepts widely discussed from 1930s through different schools of thought and is paved in empirically tested methods and mathematic models capable of translating behavior relationships. The three main foundations of network methods are the graph theory, statistics and probability theory. With these principles, SNA offer a way to define important relationship concepts.

Marteleto (2001) states that, from the first social network studies to the latest, there is no precise social network theory and that, dependent on the studied environment or on empirical data, several studies may be obtained, however, always focused at the relation between links or individuals. At the organizational environment, Borgatti \& Foster (2003) reveal the existence of a growing number of social network theories in traditional organization areas, mainly from the 1990s.

\subsection{Informal social network analysis in organizations}

SNA in organizations enables the verification of which relationship type exists among actors, including hidden relationships, in other words, links formed exteriorly to the company's organizational chart. This analysis favors the decision making, information sharing and innovation promotion, regardless of the company's size.

In their book, Cross and Parker (2004) state that even in small-sized companies, executives have been surprised in verifying that collaboration and information exchange between actors flow differently than that of the organization's organizational chart profess, confirming that collaboration is originated from a trust relationship, which extrapolates organizational charts.

Authors like Cross, Parker, Davenport, Prusak, Krackhardt and Hanson highlight the importance of informal network analysis in organizations from collaboration point of view, which generates synergy.

According to Cross and Parker (2004, p.10) "Network analysis can help ensure that such groups are collaborating appropriately and are not fragmented by physical, functional, hierarchical or organizational boundaries".

Also, Krackhardt and Hanson (1993) highlight the power of informal social networks in solving unexpected problems in organizations. Formal networks usually are established to 
anticipate problems; however in difficult times the informal social networks are the ones that come quickly forward to help solving the problems. These authors refer to the formal network established in organizations as the company's 'skeleton', in a comparison with the human body, and of informal social networks as the central nervous system branching in several directions and which, in the absence of a determined connection, is able to quickly fetch alternatives for problem solving.

From the power point of view, which extrapolates rigorous hierarchic structures, Davenport and Prusak (1998) mention the creation of "knowledge markets" in informal social network.

Informal networks of buyers, brokers and salesmen move knowledge throughout the organization. Knowledge markets are formed around formal and informal networks; therefore providing information about these networks is a good way to make knowledge visible. (DAVENPORT; PRUSAK, 1998, p.44).

Marteleto (2001) also highlights the power relation originated from information and who holds it.

\begin{abstract}
Studying information through social networks means considering power relations originated from a non hierarchic and spontaneous organization and seeking to understand to which point the knowledge and information dynamics interferes in this process. (MARTELETO, 2001, p.73).
\end{abstract}

The main benefit from informal social network analysis is discovering knowledge and information bottlenecks, as well as verifying which information type people seek the most, to who they call upon and mainly why someone reaches individual A and not B.

The informal social network idea is not new, it was previously known as informal structure or as blank parts in company's organizational charts. The possibilities that the informal social network analysis may offer to companies that are new. The conjunction of this concept with the fast advance of communication technologies widens the earning possibilities in the knowledge and innovation management areas.

\title{
1.3 Main concepts and criteria of social network analysis
}

SNA may be performed based in two approaches, a group as a whole analysis structure approach, or individual analysis - approach focused in egos, Macambira (2009). 


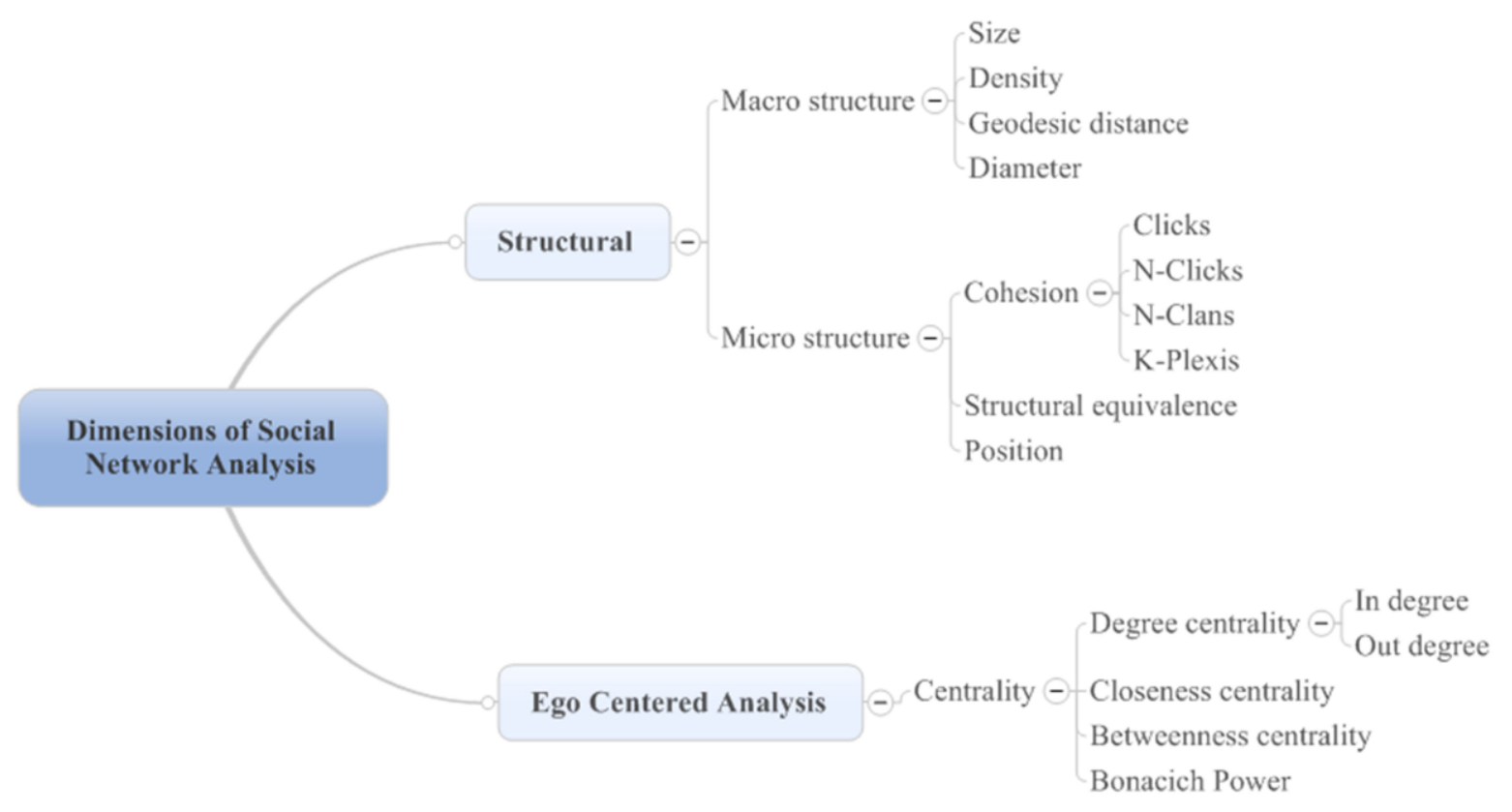

Figure 1 - Map of Dimensions of Informal Social Network Analysis Source: MACAMBIRA (2009, p.41).

According to Cross and Parker (2004), "quantitative analyses typical from networks cover both, the network as a whole and the people inserted in the network".

From density and geodesic analysis, it is possible to verify the network connectivity and its level of cohesion (LAGO, 2005).

Chart 1 - Concepts and Applications - Macro structure and Micro structure 


\begin{tabular}{|c|c|c|}
\hline Macro structure & Definition & What represents in the network \\
\hline Density & $\begin{array}{l}\text { Is the quotient between the number of existing } \\
\text { connections by the number of possible connections in } \\
\text { a determined network. }\end{array}$ & $\begin{array}{l}\text { Density represents the network potential concerning } \\
\text { information flow, i. e. the largest the density, more } \\
\text { intense is the information exchange. }\end{array}$ \\
\hline Geodesic distance & It is the shortest way between two actors. & $\begin{array}{l}\text { Generally, it is the most efficient connection between } \\
\text { two actors. }\end{array}$ \\
\hline Diameter & $\begin{array}{l}\text { It is the largest geodesic distance between any two } \\
\text { pairs of actors in a network. }\end{array}$ & $\begin{array}{l}\text { This measurement tells us how many steps are } \\
\text { required to move from one side of the network to the } \\
\text { other. }\end{array}$ \\
\hline Micro structure & Definition & What represents in the network \\
\hline Cohesion & $\begin{array}{l}\text { Average of shortest ways between each pair of actors } \\
\text { in the network. }\end{array}$ & $\begin{array}{l}\text { It concerns the strong relationship between actors of a } \\
\text { network, forming subgroups with bonds established } \\
\text { by affinity. }\end{array}$ \\
\hline Cliques & $\begin{array}{l}\text { Definition inherited from the graph theory, where two } \\
\text { or more actors choose all in the subgroup as pairs in } \\
\text { their connections. The n-clicks, n-clans and k-plexes } \\
\text { concepts are derivations of clicks. }\end{array}$ & Informally known as "cliques" in organizations. \\
\hline
\end{tabular}

Source: Adapted from Lago (2005)

From centrality analysis, it is possible to verify how the actors are concerning the position in the network, as well as the type of connectivity with other actors. Actors that are more central are the more active or with more quantity of relationships with other and are recognized as important communication channels.

Chart 2 presents the concepts of the main Centrality types, as well as a reading of how actors are recognized in the network.

Chart 2 - Centrality Concepts 


\begin{tabular}{|c|c|c|}
\hline Centrality Types & Definition & What represents in the network \\
\hline Centrality & $\begin{array}{l}\text { It is the measure of how accessible a } \\
\text { determined actor is for the remaining } \\
\text { actors of a network. }\end{array}$ & $\begin{array}{l}\text { Actors with several connections with } \\
\text { other actors have an advantage for } \\
\text { owning multiple connection } \\
\text { possibilities, generally, they are }\end{array}$ \\
\hline In-degree Centrality & $\begin{array}{l}\text { It is the measure of the number of } \\
\text { connections that an actor receives } \\
\text { from other actors. }\end{array}$ & $\begin{array}{l}\text { Actors with high in-degree centrality } \\
\text { are usually actors with high prestige in } \\
\text { the network. }\end{array}$ \\
\hline Out-degree Centrality & $\begin{array}{l}\text { It is the measure of the number of } \\
\text { connections that an actor establishes } \\
\text { with other actors. }\end{array}$ & $\begin{array}{l}\text { Actors with high out-degree centrality } \\
\text { are usually power to influence in the } \\
\text { network. }\end{array}$ \\
\hline Closeness Centrality & $\begin{array}{l}\text { It is the measure of the minimum } \\
\text { number of connections that an actor } \\
\text { needs to perform in order to establish } \\
\text { a relation with any other actor of this } \\
\text { network. }\end{array}$ & $\begin{array}{l}\text { Actors with high level of proximity } \\
\text { tend to receive information before } \\
\text { other actors. }\end{array}$ \\
\hline Betweenness Centrality & $\begin{array}{l}\text { It is the measure based on the control } \\
\text { performed by an actor over the } \\
\text { interactions between two other } \\
\text { actors. }\end{array}$ & $\begin{array}{l}\text { The largest participation of an actor in } \\
\text { the interaction control, the highest is } \\
\text { his power within the network. }\end{array}$ \\
\hline Bonacich Centrality & $\begin{array}{l}\text { It is the qualitative measure of } \\
\text { centrality, since it considers not only } \\
\text { the number of connections that an } \\
\text { actor receives, but also analyzes } \\
\text { which is connectivity of these other } \\
\text { actors in the network. }\end{array}$ & $\begin{array}{l}\text { A high Bonacich level indicates that } \\
\text { an actor, in addition to having } \\
\text { prestige, has power within the } \\
\text { network. The quality of connections is } \\
\text { more important than their quantity. }\end{array}$ \\
\hline
\end{tabular}

Source: Adapted from Lago (2005)

\subsection{Knowledge management organizations}

To understand Organizational Knowledge Management (OKM), firstly it is necessary to understand a few concepts that are usually misunderstood with knowledge. "Knowledge is neither data nor information." (DAVENPORT; PRUSAK, 1998, p.1).

A clear and simple definition of data, according to Maria Terezinha Angeloni (2008, p.1) "[...] descriptive elements of an event, lacking any logical or contextual treatment". To Davenport and Prusak (1998), data are demonstratives of something that has already happened and do not allow judgment for an eventual decision making.

For the definition of Information, the one provided by Davenport and Prusak (1998, p.4) is the best that fits in the context of this article; according to them, information is "audible and visible". To Maria Terezinha Angeloni, "The construction of information involves activities such as data collection, classification and clustering." (ANGELONI, 2008, p.1). It may be concluded that information is a set of data, which receives an analytical treatment. 
Information, in several aspects, is ideal to transmit explicit knowledge (SVEIBY, 1998). Knowledge is a much wider concept. To Maria Terezinha Angeloni (2008), it is not synonymous for information accrued. As the article if focused in the organizational environment, the most useful definition of Knowledge is the one provided by Davenport and Prusak.

\begin{abstract}
Knowledge is a fluid mix of framed experience, values, contextual information and expert insight, that provides a framework for evaluating and incorporating new experiences and information. It originates and is applied in the minds of knowers. In organizations, it often becomes embedded not only in documents or repositories, but also in organizational routines, processes, practices and norms. (DAVENPORT; PRUSAK, 1998, p.6).
\end{abstract}

Davenport and Prusak (1998) also suggest that in order to understand the concept of knowledge, it is necessary to understand a few basic structures of knowledge composition, such as: experience, truth, discernment, norms - practices and values and beliefs. All these elements depend on the human being to be experienced.

Several authors mentioned by Nonaka and Takeuchi (1997), as Taylor, Mayo, Barnard and Drucker, have developed theories for the creation and dissemination of knowledge in organizations. A few antagonistic, as Taylor and Mayo, that suggest a more technical approach in contrast with a more humanistic view (Scientific Administration Theory of Taylor versus Human Relations Theory of Mayo); others, according to the authors, incomplete for excessively dedicating with strategies leaving the processes aside. In all of them, however, the concern with recreating the environment is verified, searching for competitive differentiation and innovation through organizational knowledge.

Prusak and Davenport have already affirmed that knowledge is not something new.

New is to recognize the knowledge as a corporate asset and understand the need to manage and surround it with the same care dedicated for obtaining value from other more tangible assets. The necessity of extracting the maximum value from knowledge is currently larger than in the past. (DAVENPORT; PRUSAK, 1998, P.15).

To Davenport and Prusak (1998), knowledge is valued in organizations because it is close to the action, more than data and information. "The only sustainable advantage that a Company has is what it collectively knows, the efficiency with which it uses what it knows and the readiness with which it acquires and uses new knowledge“ (DAVENPORT; PRUSAK, 1998, presentation XV). 
Data, information and knowledge are distinct elements and at the same time complementary in the gear of knowledge management, which exempts great technologies to exist. ": Knowledge derives from information in the same way as information derives from data" (DAVENPORT; PRUSAK, 1998, p. 6-7). Their quality does not oblige the use of sophisticated information technologies. What was gained with advanced technologies was the easiness with which it is possible to disseminate and store them.

An example used by Davenport and Prusak (1998) in their book to demonstrate that the communication medium is not the message, regards the telephone, which, however sophisticated it may be, it will never be able to make conversations fought them high quality.

These authors have also demonstrated that knowledge markets in organizations have well defined actors as: buyers, salesmen and knowledge agents; where the main currencies are: a. reciprocity, b. reputation and c. altruism. Active knowledge gains more importance in organizations and those who possess this asset, people, are more stimulated to participate in the commerce for the construction of a corporate knowledge capable of bringing sustainable competitive advantages for the organization. There is, however, an important element in the occurrence of the called knowledge markets which may even overlap other factors, as Davenport and Prusak (1998) affirm - trust, present in any informal transaction. Trust must be respected and it must be observed if it occurs from top to bottom, if it is generalized and visible, in other words, there must be recognition from the organization to the members that share its knowledge.

Nonaka and Takeuchi (1997) also affirm that "the organization that desires to deal in a dynamic manner with environmental changes must create information and knowledge, not only process it efficiently".

In the knowledge society, the main modifying agent in organizations is the human being, categorized by Drucker (1993 apud NONAKA e TAKEUCHI, 1997, p.51) as "knowledge laborer". The knowledge laborer is a central figure in the transformation of tacit knowledge in explicit knowledge. Nonaka e Takeuchi (1997) note, however, that, despite Drucker recognized tacit knowledge in its importance, highlighting that ability may not be explain only with words being transmitted through experiences, also admits the coexistence of scientific methods to transform experiences in systems or something that may be learned, suggesting a view closer to Taylors scientific view.

To Sveiby (1998) people are the real agents in the organization and all tangible and intangible assets result from their actions. 
The definition of tacit and explicit knowledge concepts is the basis for understanding the knowledge conversion model proposed by Nonaka and Takeuchi (1997); they are the main axis that move the knowledge transfer dynamic. They have based the model development in Michael Polanyi's definition (1966) which establishes tacit knowledge as the knowledge difficult to be formulated, transmitted and shared, since it is personal, in other words, based in personal values. Explicit knowledge is based in codification, in formal language, capable of being transmitted.

Data and information are means of obtaining knowledge. According to Davenport and Prusak (1998), the human being is capable of assimilating these two elements and adding personal experiences, values and beliefs and discernment in order to obtain knowledge.

According to Nonaka and Takeuchi (1997) highly subjective conclusions, insights and guesses are integrant part of the knowledge, are part of tacit personal and hard to be captured knowledge. Knowledge also covers ideas, values and emotions, as well as images and symbols, all these elements are present in the human nature.

The companies' great challenge is measuring the gains associated to the implementation of a knowledge management. There is a clear need for investment, both in technologies, to facilitate communication, and in a change management for internal processes of the organization. To seek information, work it out and transform it in knowledge capable of being transmitted to other collaborators also requires the consumption of a highly valuable organizational resource - time. "Company members must have time for buying knowledge" (DAVENPORT; PRUSAK, 1998, p.56).

\section{METHODOLOGY}

The present article is based in a case study of explanatory type, which, according to Joia (2006), is one of the three main types of case studies, begin greatly used in researches aimed at explaining the relationship between different components of the case in a casual relation. For the research classification, we used the taxonomy presented by Vergara (2010), which qualifies the research in two basic criteria, concerning the ends and the means.

Concerning the ends is an applied and descriptive research with qualitative and quantitative approaches. According to the theory rehearsal of Fernandes (2010) for the development of a research based in SNA study, it is necessary to use both quantitative and qualitative approaches. The quantitative approach deals with the interaction quantity; the 
qualitative approach analyzes the subjective areas of social behavior, such as: trust and collaboration in information and knowledge exchange.

The research is applied because it seeks to solve real or concrete, more immediate problems, and descriptive because it seeks, within the population composed by six managements of EB-E\&P, to understand how interpersonal relationships occur.

To validate the case study, a research was held from questionnaires for work force, composed by Petrobras' employees and outsourced employees. Data was analyzed in function of the managements, technical level and physical employee location. Metrics were globally analyzed.

\subsection{Research Universe}

The research population was composed by E\&P basic engineering employees, totalizing at the data collection time 168 people, of which 111 were Petrobras employees and 57 were outsourced employees. The research sample was defined by accessibility criterion (Vergara, 2010), being composed by 106 employees, representing 61\% of E\&P basic engineering employees, among their and outsourced employees. In the sample constitution, we aimed at representing all managements. The sample was basically formed by engineers from several disciplines, all involved in the execution of basic engineering projects, technical assistance and research and development projects (R\&D).

\subsection{Data collection}

The research was performed between July and October 2011. Data collection was held in two stages. The first phase with four employees (three Petrobras' employees, and one outsourced employee). In the second phase, questionnaires were applied with closed questions directed to the subject "information and knowledge transfer through informal social networks". To the participants, information secrecy was ensured.

Codes were used to replace the employees' names. This coding was important to preserve the participants' identity, thus ensuring a larger adherence. The coding was elaborated using the employee's management acronym plus the numerical sequence; for example, in the GPEP management employee list, the first employee received the GPEP01 code, the second in alphabetical order receive the GPEP02 code and so on. The employee 
coding contributed also for an analysis free of any emotion from the author, who provided services for one of the studied managements.

The questionnaires were hand-delivered to the participants, and each one was identified, or 'coded', in the answer form at the time of adherence to the research with their respective code. The intention with the approach was to increase the participant's trust in order to obtain the most realistic answers (this perception was identified in the first phase of the questionnaire). The largest part of participants preferred not to answer the questions in the researcher's presence, requesting time and privacy. Since it concerns an approach that exposes the participants' type of relationship, the request was accepted by the researcher.

For questions regarding SNA, to the participants was provided a list with name and management of all employees that were at E\&P basic engineering in the period between July and October 2011

The presented questionnaire was adapted from questionnaires suggested by Cross and Parker (2004, p.147-148), and four factors were chosen for this research's analysis: information, knowledge, trust and friendship.

\subsection{Data application and analysis}

Data analysis was held through commercial tools of SNA, UCINET and NETDRAW, which enabled the elaboration of matrixes and generated graphs for visual analysis from mathematic data.

The adjacency matrix used is, according to Hanneman and Riddle (2005), the most common matrix for social analysis, for being binary. The adjacency matrix or socio-matrix, Wasserman and Faust (1994), indicates if the actors are adjacent or not, from entry binary data.

The matrix is also squared and identical, according to Velásquez and Aguilar (2005), "the matrix is squared when the number of lines is equal to the number of columns, and is identical when the number and name of lines and columns are equal". Thus, five squared and identical matrixes were plotted, each for one researched question. 106 lines and 106 columns with the participants' codes were inserted in the matrix. Since it is an adjacency matrix, the relation between actors was demonstrated using the number 0 and 1 . The concept of this matrix is simple, if there is a link between actors, represented by lines in the network, these 
actors are adjacent or close and this relation will be plotted in the matrix with the number 1 ; however, if there are no links or relationships between two actors, the plotted value will be 0 .

Another simple matrix concept is that "an adjacency matrix may be symmetrical or nonsymmetrical", Hanneman and Riddle (2005). The matrix is symmetrical when there is bidirectional relationship between actors; and it is nonsymmetrical when the relationship between pairs of actors is recognized only by one actor.

After the collection period, data was plotted in the UCINET software. The analysis was held firstly considering the network dimension structure for the four analysis factors: information, knowledge, trust and friendship; next, the actors' position in the network was analyzed. For each analysis factor, routines from the UCINET software were used, as well as the following metrics:

Chart 3 - Dimension of the research analysis

\begin{tabular}{|c|c|c|c|c|c|}
\hline \multirow{3}{*}{ SNA Metrics } & \multicolumn{5}{|c|}{ Analysis Factors } \\
\hline & \multicolumn{2}{|c|}{ Information } & \multirow[t]{2}{*}{ Knowledge } & \multirow[t]{2}{*}{ Trust } & \multirow[t]{2}{*}{ Friendship } \\
\hline & $\begin{array}{c}\text { Entry } \\
\text { Information }\end{array}$ & $\begin{array}{c}\text { Exit } \\
\text { Information }\end{array}$ & & & \\
\hline \multicolumn{6}{|c|}{ Macro Structure Analysis } \\
\hline \multicolumn{6}{|l|}{ Geodesic Distance } \\
\hline \multicolumn{6}{|l|}{ Diameter } \\
\hline \multicolumn{6}{|l|}{ Density \% } \\
\hline \multicolumn{6}{|c|}{ Ego Centered Analysis } \\
\hline \multicolumn{6}{|l|}{ In-degree Centrality } \\
\hline \multicolumn{6}{|l|}{ Betweenneess Centrality } \\
\hline Closeness Centrality & & & & & \\
\hline
\end{tabular}

Source: Elaborated by the author

To facilitate the network visualization and analysis, attributes were created for each management of E\&P basic engineering. The attribute of a node, or actor, is a characteristic input to it through NETDRAW software and is used to differentiate it. Attributes are particularly useful in large networks.

Colors were defined as a differentiation attribute of EB-E\&P managements, according to the following legend:

$\begin{array}{lll}\square \text { GG } & \square \text { GPEP } & \square \text { PPEP } \\ \square \text { EPN } & \square \text { FP } & \square \text { EG }\end{array}$

To distinguish the site where professionals are physically developing projects, three symbols of NETDRAW tool were used, according to the following legend:

\section{CENPES Site}




\section{Contracted Site \\ $\triangle$ Both Sites}

\subsection{Research limitations}

The adopted criterion for the present research was to use only participants of the questionnaire in data plotting, thus, if an actor is mentioned in the research but was not part of it, he is not considered in the analysis.

\section{STUDY OBJECT}

\subsection{Description of the research's organization environment}

The present research was developed at the Basic Engineering general management at E\&P, in Petrobras Research Center (CENPES), a technology unit associated with Petrobras Engineering, Technology and Material Direction, the largest research center in Latin America today. "In the Basic Engineering area, CENPES has capacity to elaborate projects that meet Petrobras demands, being the country's largest organization in the area" (PIMENTA, 2006, p.135). It concerns an intellectual production environment that involves several disciplines in basic project development and technical assistance.

Basic engineering is composed by six functional managements, Project Portfolio Management for Exploration and Production (GPEP), Project Engineering for Exploration and Production (EPEP), Naval Engineering (EN), Structures and Geotechnics (EG), Production Facilities (FP), Production Processes (PPEP) and one General Management of EB $-\mathrm{E} \& \mathrm{P}(\mathrm{GG})^{1}$. Each management is responsible for a set of disciplines that actively interact in basic project development and technical assistances.

The project manager in organizational chart of EB-E\&P, or in the formal structure, is the project coordinator, who belongs to GPEP management. The project coordinator requests resources from other functional managements, according to the project specifics, and has a moderate to high authority over the resources. Some of the project's critic resources, which belong to Petrobra's staff, sometimes are requested to develop activities in their functional

\footnotetext{
${ }^{1}$ Acronyms used in Portuguese.
} 
managements and thus accrue responsibility to generate and disseminate information both in the project and in the management in which they are located, being able to develop into a bottleneck.

There's a concern in the company regarding the training of new employees. The training of new people is usually designated to discipline senior engineers, however these resources are widely requested (critical resources), which makes their performance difficult in disseminating knowledge.

Functional managers perform the roll of guiding the their management team and also are responsible for being the knowledge disseminating agent, however, they are more and more involved in management issues.

Explicit knowledge sharing at CENPES in facilitated by Petrobras intranet through systems as: Standardization System, Abnormality Management System, Petrobras's Community of Practice, Technical Standards and Publications, nevertheless, as noticed by Pimenta (2006, p.98), despite the large information storage structure and data base with competence mapping, people (at CENPES) consult their work colleagues for any information. There is, at the time, no learnt lesson bank at EB-E\&P capable to provide feedback to future projects and capacitating new employees at the speed that the company needs.

This moment appears particularly interesting for a knowledge management approach at E\&P basic engineering, since, at the same time that it is necessary to produce more, it is also necessary to train more people in less time, in order to suppress the lack of specialized technical resources.

\subsection{Analysis and discussion of results}

\subsubsection{Respondents profiles analysis}

With the present research, we aimed at verifying if there is any relationship in the distance between companies that develop basic projects, which means, if physical barriers were created between actors. Of the 106 employees that participated in the research, $73 \%$ are located at CENPES. The remaining $27 \%$ are basically composed by project coordinators and discipline leaders that perform and coordinate projects at the contracted companies, outside CENPES. 
Education level is quite high, of the 106 employee sample, 93\% have higher education, of which $61 \%$ have latu sensu and strictu sensu specialization and around $14 \%$ are attending to post-graduation, masters and doctors degrees, what will soon elevate this percentage to $75 \%$ of professionals with latu sensu and strictu sensu specialization. The $7 \%$ with secondary education (technical education) basically develop a support roll, are composed by administration personal and only one employee belongs to Petrobras.

The interviewee's seniority is quite high, $69 \%$ of the interviewees are formed by senior level or mid-level employees. The amount of $22 \%$ of junior level employees in this sample is highly significant; this data reinforces the company's strategy of renewing the work force by attracting new talents.

In this sample, one quart of employees is at E\&P basic engineering for over ten years. This number is highly representative, since these professionals with high business knowledge are the main indicated to maintain a knowledge replicator relationship.

\subsubsection{Informal social network analysis}

\subsubsection{Network macro structure analysis}

The analysis of the four ISN factors - information (EI) and (ExI), knowledge (KL), trust (TR) and friendship (FS) - was initially performed considering the network as a whole. In a Macro Structure dimension, the network was analyzed through metrics: Geodesic Distance, Diameter and Density. Next, the analysis was held based in egos or individuals that constitute the network.

For the Information factor analysis, the participants were requested to identify work colleagues through the following statements:

EI - Entry Information:

I obtain from this person clear information to develop my work.

ExI-Exit Information:

I provide information to this person whenever I'm requested.

Two matrixes were plotted, one with entry information (EI) and another with exit information (ExI). This distinction was necessary to understand what is important in the 
actors' perception in terms of information circulation. The results were quite similar between EI and ExI.

The average geodesic distance from both networks is of 2.217 for EI and 2.058 for ExI, demonstrating that to reach any other contact in the network an actor requires, averagely, two (2) contacts in any of these networks. This measure indicates that both to EI as to ExI, the networks are highly connected, enabling quickness in information spread.

The network diameter reveals that both networks are average in terms of size, to go from one side of EI network to the other five relations are required; and for ExI, four relations are required. This means that the maximum number of relations that the actors need to reach another actor in the information network is five to EI and four to ExI.

The ExI network density is $18.34 \%$, slightly larger than the EI density of $14.70 \%$. Both are reasonably dense, showing a good information flow. The difference between densities means having a greater perception of the provided information (ExI) than of the received information $(\mathrm{EI})$.

Chart 4 - Network Information (Entry and Exit) - Macro structure data

\begin{tabular}{|l|c|c|}
\hline \multicolumn{3}{|c|}{ Network Information } \\
\hline SNA Metrics & EI_Entry Information & ExI_Exit Information \\
\hline Geodesic Distance & 2.217 & 2.058 \\
\hline Diameter & 5 & 4 \\
\hline Density & $14.70 \%$ & $18.34 \%$ \\
\hline
\end{tabular}

Source: Elaborated by the author 
Figure 2 - Entry Information (EI) - Informal Social Network Map

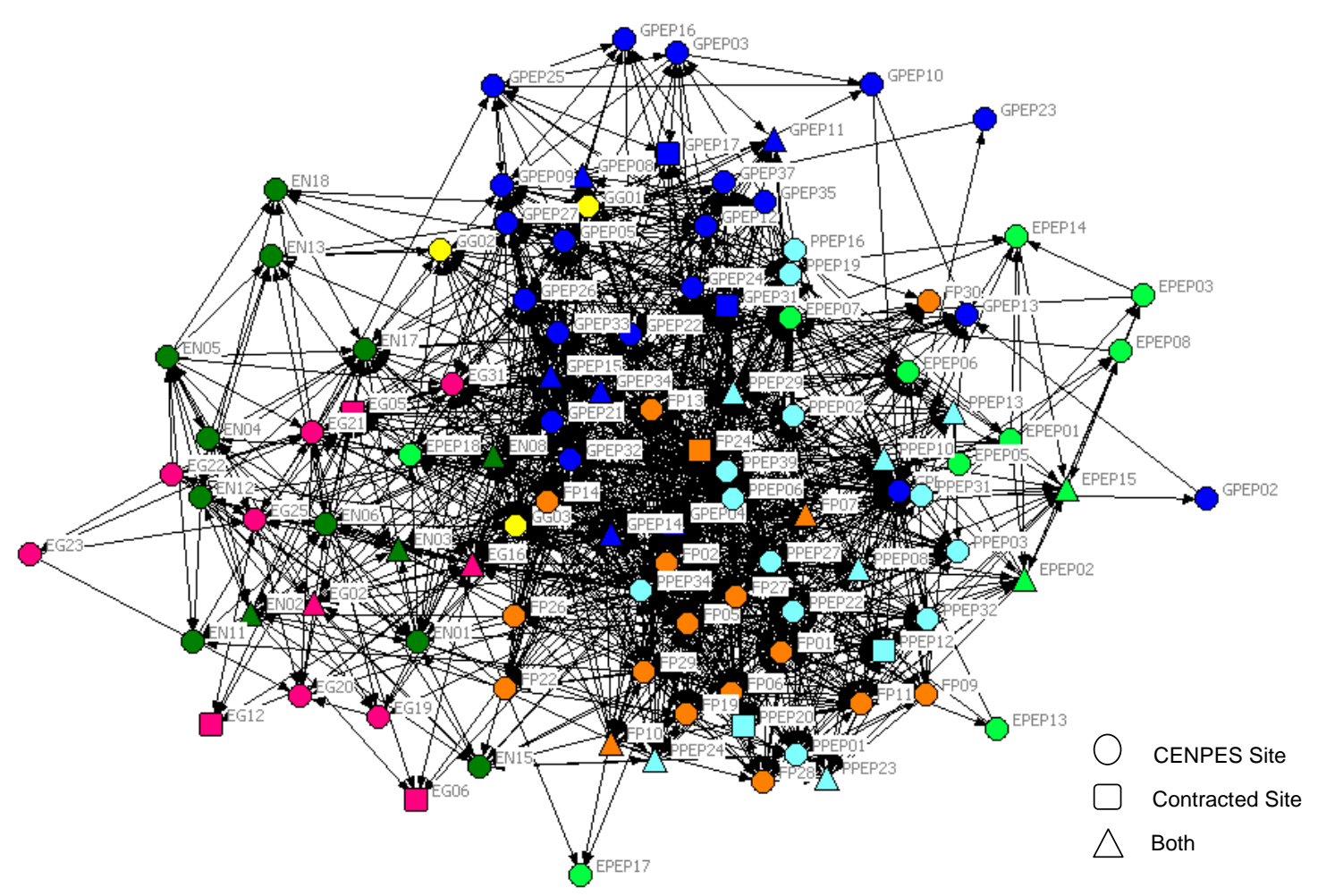

Source: Elaborated by the author

Figure 3 - Exit Information (ExI) - Informal Social Network Map 


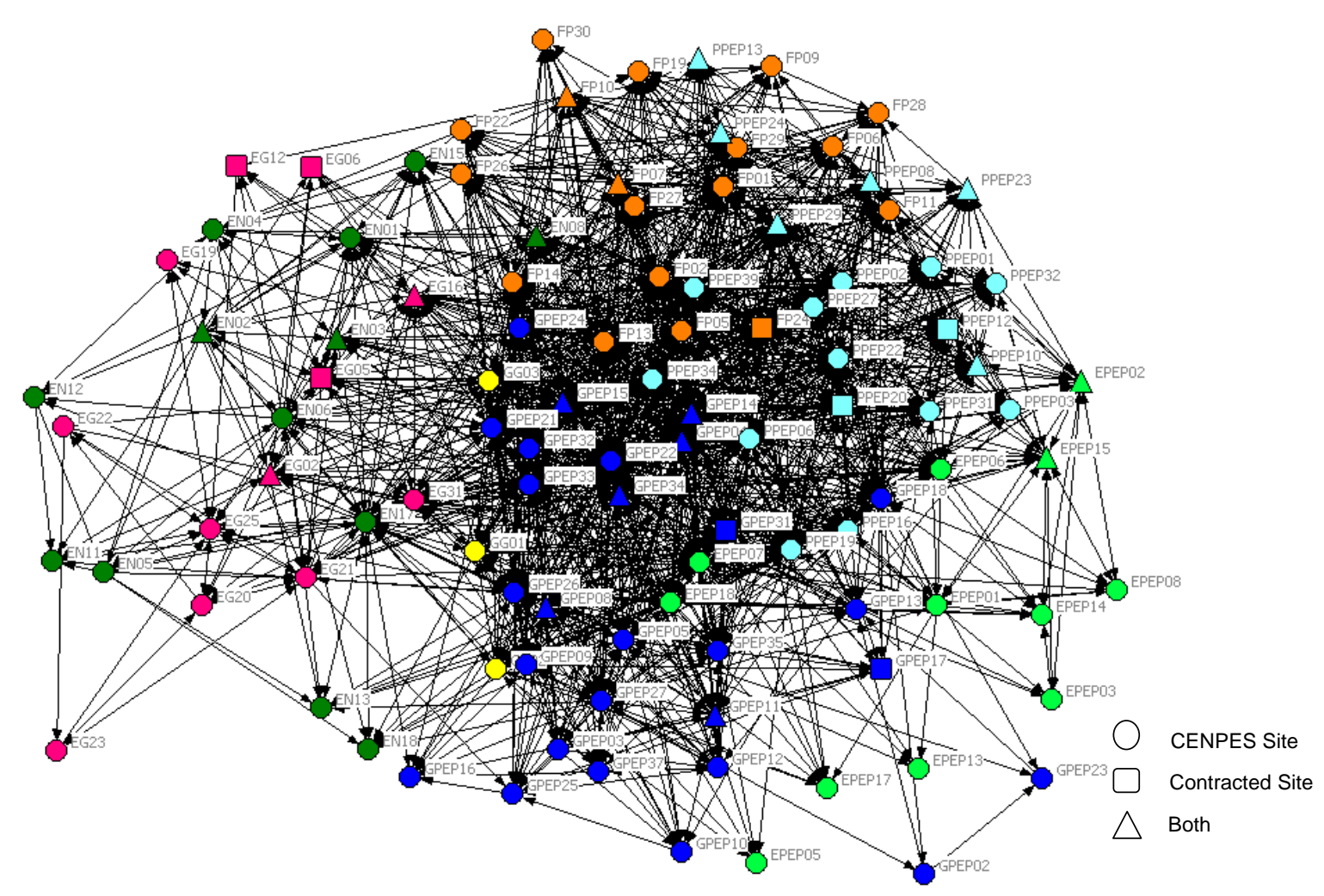

Source: Elaborated by the author

The maps of EI and ExI networks generated by the NETDRAW software, in Figures 2 and 3, evidence managements FP and PPEP as the densest. This means that there is large information exchange flow in these managements; however, it is not clear in the maps whether the density of the two managements is permeating other managements at E\&P basic engineering, thus, evidencing information exchange between the managements. This view generated the necessity, from the researcher, to verify the density relation between the managements. UCINET tool allows a density analysis by group or, in the case of this study, by management. As a result from this analysis, observed is Charts 5 and 6, FP and PPEP managements were confirmed as the densest managements, demonstrating that information circulates with higher intensity internally in the managements. In EI case, the higher indicators are of functional managements to GPEP, what is justified due to the allocation of project coordinators in this management. In the group analysis, it was possible to highlight the GG management, which did not appear to present a high density in Figure 2.

In ExI, the highlight is between technical managements and GG, confirming the leadership position of this management at project conduction. 
Chart 5 - Density of Entry Information Network by Management

\begin{tabular}{|l|c|c|c|c|c|c|c|}
\hline \multicolumn{1}{|c}{ EI } & \multicolumn{1}{c}{ GG } & \multicolumn{1}{c}{ GPEP } & EPEP & EN & EG & FP & PPEP \\
\hline GG & $83 \%$ & $25 \%$ & $14 \%$ & $18 \%$ & $22 \%$ & $15 \%$ & $15 \%$ \\
\hline GPEP & $26 \%$ & $27 \%$ & $8 \%$ & $5 \%$ & $7 \%$ & $13 \%$ & $13 \%$ \\
\hline EPEP & $8 \%$ & $3 \%$ & $21 \%$ & $1 \%$ & $0 \%$ & $2 \%$ & $11 \%$ \\
\hline EN & $13 \%$ & $5 \%$ & $2 \%$ & $35 \%$ & $15 \%$ & $1 \%$ & $4 \%$ \\
\hline EG & $17 \%$ & $12 \%$ & $2 \%$ & $12 \%$ & $31 \%$ & $3 \%$ & $3 \%$ \\
\hline FP & $17 \%$ & $19 \%$ & $4 \%$ & $9 \%$ & $4 \%$ & $55 \%$ & $29 \%$ \\
\hline PPEP & $15 \%$ & $19 \%$ & $12 \%$ & $7 \%$ & $6 \%$ & $23 \%$ & $42 \%$ \\
\hline
\end{tabular}

Source: Elaborated by the author

Chart 6 - Density of Exit Information Network by Management

\begin{tabular}{|l|c|c|c|c|c|c|c|}
\hline \multicolumn{1}{|c|}{ ExI } & GG & GPEP & EPEP & EN & EG & FP & PPEP \\
\hline GG & $83 \%$ & $36 \%$ & $19 \%$ & $21 \%$ & $22 \%$ & $17 \%$ & $15 \%$ \\
\hline GPEP & $31 \%$ & $39 \%$ & $12 \%$ & $9 \%$ & $10 \%$ & $18 \%$ & $16 \%$ \\
\hline EPEP & $17 \%$ & $10 \%$ & $42 \%$ & $5 \%$ & $4 \%$ & $5 \%$ & $18 \%$ \\
\hline EN & $18 \%$ & $9 \%$ & $1 \%$ & $41 \%$ & $22 \%$ & $2 \%$ & $3 \%$ \\
\hline EG & $17 \%$ & $10 \%$ & $1 \%$ & $6 \%$ & $30 \%$ & $1 \%$ & $2 \%$ \\
\hline FP & $28 \%$ & $23 \%$ & $7 \%$ & $8 \%$ & $6 \%$ & $59 \%$ & $25 \%$ \\
PPEP & $25 \%$ & $22 \%$ & $16 \%$ & $7 \%$ & $6 \%$ & $22 \%$ & $55 \%$ \\
\hline
\end{tabular}

Source: Elaborated by the author

\subsubsection{Centered Analysis in Egos}

To identify which actors develop a highlighted roll in the network, a centrality study was performed based in Egos for the four analysis factors: information, knowledge, trust and friendship, in order to identify actors with power of creating technical knowledge within the network. Thus, at the present article, the levels of entry and exit centrality, intermediation centrality and proximity centrality were calculated for the actors that constitute the network. 
According to Velásquez e Aguilar (2005), the centrality degree is the number of actors to which an actor is directly connected, being the in-degree centrality a measure that demonstrate popularity or prestige of a determined actor, since it reports the number of ties or connections that this actor receives from other actors in the network. The out-degree centrality reports the expansivity of an actor, for this measure indicates the number of links that an actor establishes with other actors in the network. To Hanneman (2000), actors with a high centrality degree are less dependent, since they have more ties than other actors, have more possibilities to access in the network.

The betweenness centrality analysis enables the identification of actors that have control to intermediate interactions between two other actors; they are called 'bridge actors'. This measure is obtained by counting the number of times that a determined actor appears in geodesic paths that connect other actors in the network, according to Velásquez and Aguilar (2005).

With the closeness centrality analysis, it is possible to verify an actor's position in the network. Being more central in the network means being able to reach other network ties in short distances. This measure is obtained by counting all the geodesic paths of an actor to connect with the remaining network and, according to Marteleto (2001), indicates the actors independence regarding the control of others, the smaller the geodesic distance, the higher the closeness centrality.

For the purposes of the analysis, as criterion in the present study, the twenty highest values of research actors were highlighted, calculates through the UCINET software for indegree centrality, betweenness centrality and closeness centrality indicators.

In a comparison between absolute in-degree centrality values, demonstrated in Figure 4 , in other words, verifying the actors that received more ties from other actors, it is noticed that senior level, which represent $26 \%$ of the sample, are the most recognized in all the analysis factors; and that the analysis factor of technical knowledge is associated to other factors as trust and information exchange (entry and exit information). The friendship factor is not an indicator that favors neither the information exchange nor the recognition of references in technical knowledge, despite it representing a higher density than those. Thus, we conclude that senior level are more expansive in terms of information exchange, are more reliable to guide and listen to professional problems and are also reference in terms of technical knowledge. 
Regarding mid-level professionals, we notice that there are collaboration elements highlighted, as information exchange, as well as a good trust relation, suggesting that in this group workers could be performed to make them technical knowledge replicators. It is worth mentioning that seniors level are highly demanded by work force; in addition to performing their activities of execution, coordination and management functions, they still have a large participation in interpersonal relations.

Figure 4 -In-degree centrality - Main Actors

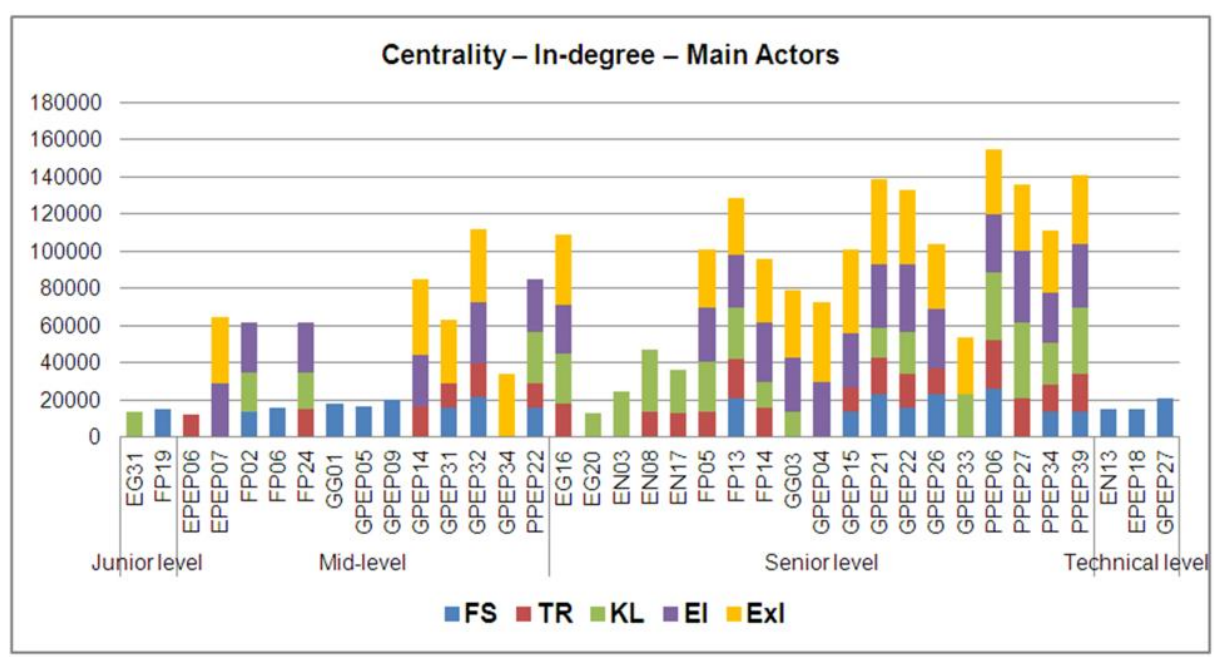

Source: Elaborated by the author.

At the comparison between absolute values of betweenness centrality, Figure 5, i. e., the actors that perform control in interactions between two other actors in the network, among the twenty first values of each analysis factor, the seniors level are also majority for all analysis factors, as well as a significant number of mid-level, which grants them power in socio-organizational relations at EB-E\&P.

Figure 5 - Betweenness Centrality - Main Actors 


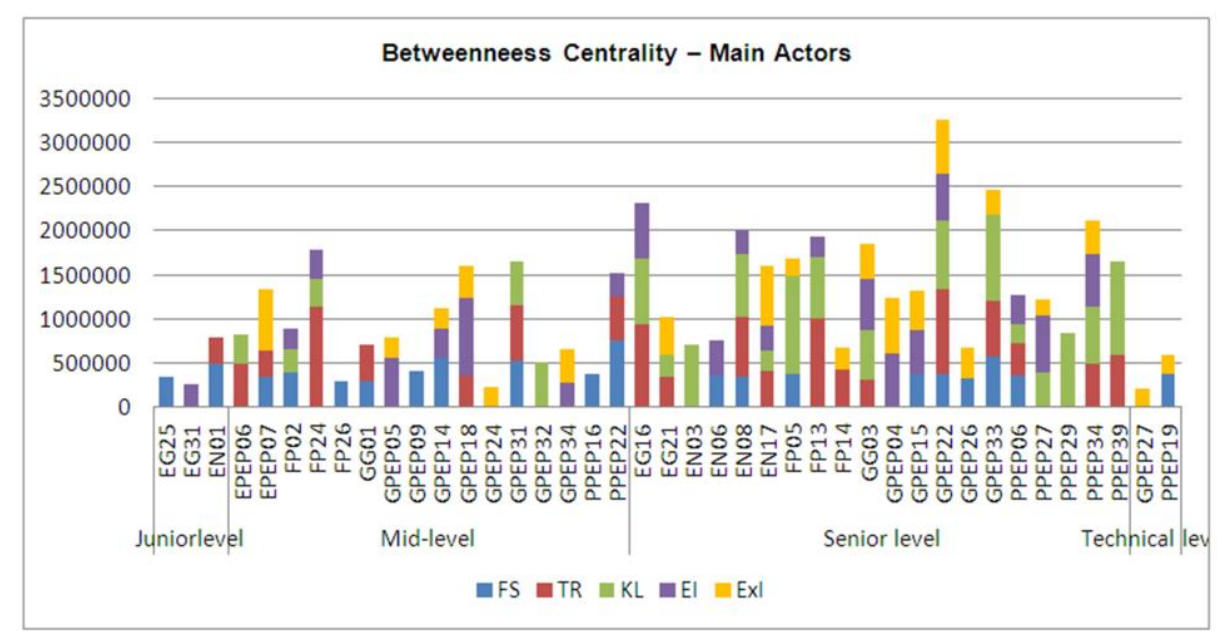

Source: Elaborated by the Author

Comparing the actors that more frequently request information with those that more frequently send information in the network, it is possible to verify who are the actors that effectively participate at the information exchange, functioning as central connectors, highlighted in red on figure 6, and may be considered key-people at the information and knowledge transmission. According to Cross and Parker (2004), actors that function as central connectors may be positive for the network as a whole and are considered valuable for the organization, but also may be a problem, especially when this high connectivity, which covers activities of helping other people such as placing people in contact with one another, answering directly when requested, being involved in problem solving, among others, consume many hours of more central actors, enabling them to become information and knowledge bottlenecks within the organization.

Figure 6 - Information Connecting Actors 


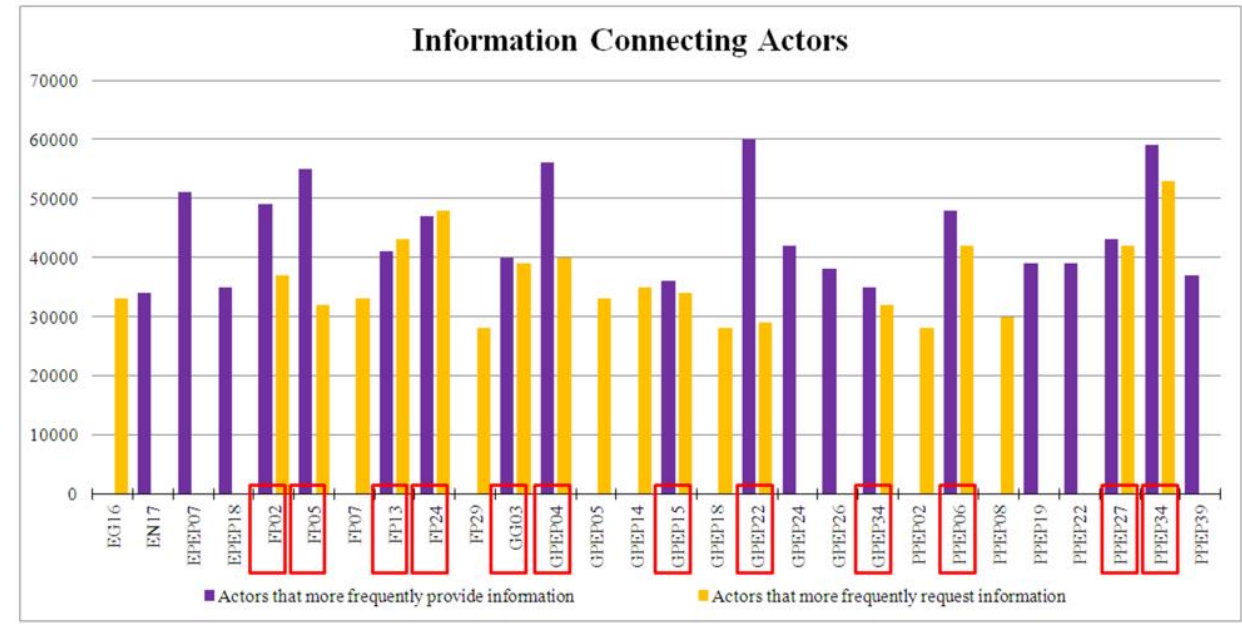

Source: Elaborated by the author

\section{CONCLUSIONS}

Informal Social Network Analysis is an important tool at the knowledge management process in organizations. From SNA, it is possible to know the main vehicle of tacit knowledge transfer, the human being. The manner with which man organizes himself influences the environment and is able to make the difference, either positively or negatively, depending on how he organizes himself and with what purpose.

According to the analyzed bibliography, the greatest mistake that organizations make when attempting to implement knowledge management is to give much emphasis to technology in detriment of the human being. Generally, this occurs because technology is something palpable, easy to purchase and measure; yet "Tacit knowledge is, sometimes, explicable, more frequently is demonstrable" (STEWART, 2002, p.193) and requires the human being to decode it and transform it into action, based in principles and organizational processes.

It should be sought to facilitate the interaction between actors of an organization in order to promote the construction of solid relationships based in trust. This interaction is particularly positive for the activation of the social network. "Data and information are constantly transferred by electronic means, but knowledge appears to transit more efficiently through human networks" (DAVENPORT; PRUSAK, 1998, p.193).

The present research sought to analyze how occurs the interaction between actors of a group of multidisciplinary and complementary managements in the production of an engineering product composed by almost two thousand technical documents and, from this 
informal interaction, map how information actually flows between these managements and how technical knowledge permeates the people involved in knowledge transfer, either by friendship or by trust between members of this team.

We concluded, from the densities of information, trust, knowledge and friendship networks, that the largest densities observed occurs within managements, what reveals little informal interaction between managements and that the managements are generally closed groups. Only in the 'information' analysis factor there is some permeability, mainly between functional managements GPEP, EG, EN, FP and PPEP with the general management GG and vice versa.

The main actors of these networks were identified, as well as the relation between ISN with the technical level of each one, since one of the objectives was to know who are the actors that operate as replicators and connectors of information and knowledge. With the data obtained in the study, it was verified that in the group of actors that constitute E\&P basic engineering, which is formed by people with high seniority and high education level, the trust relation is more associated with information exchange and expertise recognition than to the friendship relation.

It was also of the research interest to analyze if there is a type of information bottleneck, since a significant sample of employees from the studied managements participated in the research.

The actors that interact more with managements are the senior professionals. Among the 28 senior professionals in the sample, 19 appear between the twenty more connected actors in the four analysis factors, this demonstrates that the seniors level contribution in knowledge transfer is highly relevant, since in addition to participate in the productive process, making information flow, they are the people that inspire more trust for professional guidance and are the most recognized in terms of technical knowledge. Senior professionals are the only ones that have mobility and recognition is all managements and may be considered as technical bottlenecks.

At E\&P basic engineering, the necessity of having larger cohesion between managements is verified in order to knowledge be shared. According to Davenport and Prusak (1998, p.115), "tacit knowledge transfer generally demands intense personal contact", something that is facilitated by ISN. There must be, however, organizational guidance and motivational factors for knowledge transfer, so everyone participate in this process. 
Research data alert that, for the implementation of any organizational change, there will be a strong segmentation due to the managements being closed and will demand a wide work focused in behavior and cultural changes.

\section{REFERENCES}

ALEJANDRO, V. A.; NORMAN, A. G. Manual introdutório à Análise de Redes Sociais. Toluca: UAEM - Universidad Autónoma Del Estado de México, 2005. 45 p.

ANGELONI, M. T. (Org.). Gestão do Conhecimento no Brasil: casos, experiências e práticas de empresas públicas. Rio de Janeiro: Qualitymark, 2008. 209 p.

ANGELONI, M. T. (Org.). Organizações do Conhecimento: infraestrutura, pessoas e tecnologia. 2. ed. São Paulo: Saraiva, 2008. 363p.

ARGOTE, L.; McEVILU, B.; REAGANS, R. Managing Knowledge in Organizations: An Integrative Framework and Review of Emerging Themes. Management Science, Catonsville, v. 49, n. 4, p. 571-582, apr. 2003.

BOOTH, W. C.; COLOMB, G.G.; WILliAMS, J. M. A arte da pesquisa. 2. ed. São Paulo: Martins Fontes, 2005. 351 p.

BORGATTI, P. S.; FOSTER, C. P. The Network Paradigm in Organization Research: A Review and Typology. Journal of Management, Thousand Oaks, v. 29, n. 6, p. 991-1013, 2003.

CAMPBELL, H.M. The liberation of Intellectual Capital through the natural evolution of Knowledge Management Systems. Vanderbijlpark, África do Sul: Vaal University of Technology, 2010. p. 218-225.

CHINOWSKY, S. P.; DIEKMANN, J.; O'BRIEN, J. Project Organizations as Social Networks. Journal of Construction Engineering and Management, Reston, v. 136, n. 4, p. 452-458, apr. 2010.

COSTA, A. R.; MEIRA, R. L. S.; SILVA, M. E.; RIBEIRO A. R. Um Processo para Gestão do Conhecimento Organizacional através de Redes Sociais. In: SIMPÓSIO BRASILEIRO DE SISTEMAS COLABORATIVOS, 6., 2009, Recife. Anais eletrônicos... Recife: SBC, 2009. Disponível em: <http://www.sbc.org.br/sbsc2009/programacao.html>. Acesso em: 19 jun. 2010.

CROSS, R.; PARKER, A. The Hidden Power of Social Networks. Boston: Harvard Business School, 2004. 213 p.

DAVENPORT, T. H.; PRUSAK, L. Conhecimento empresarial: como as organizações gerenciam o seu capital intelectual. 12. ed. Rio de Janeiro: Campus, 1998. p. 237. 
FERNANDES, R. C. O método de Análise de Redes Sociais como mecanismo híbrido de pesquisa em apoio a sua teoria. In: CONGRESSO INTERNACIONAL DE

ADMINISTRAÇÃO, 2010, Paraná. Anais eletrônicos... Recife. Disponível em: <http://www.admpg.com.br/2010/index.php?id=89>. Acesso em: 10 out. 2010.

GUEDES, A. L. A. A Percepção da Transmissão do Conhecimento nas Redes Sociais Informais (RSI) de Atendimento ao cliente: estudo de uma empresa pública de tecnologia da informação e comunicação. 2010. 124 f. Dissertação (Mestrado em Sistemas de Gestão) Universidade Federal Fluminense, Rio de Janeiro. 2010.

HANNEMAN, R. A.; Riddle M. Introduction to social network methods. Riverside, CA: University of California, 2005. Disponível em: <http://faculty.ucr.edu/ hanneman/>. Acesso em: 14 mar. 2012.

HAYTHORNTHWAITE, C. Social network analysis: an approach and technique for the study of information exchange. Library and Information Science Research, Illinois, v. 18, p. 323-342, aut. 1996.

HONG, C. D.; LING, H.; ZHANG, H. C., LI, M. Y. Theoretical Insight into The Mechanism of Knowledge Integration. Information Management and Engineering (ICIME), apr. 2010. Disponível em: <http://ieeexplore.ieee.org/document/5477998/>. Acesso em: 16 out. 2010.

JOIA, L. A. Geração de Modelos Teóricos a partir de estudos de casos múltiplos: da teoria a prática. In: VIEIRA, Marcelo Milano Falcão; ZOUAIN, Deborah Moraes (Org.). Pesquisa Qualitativa em Administração. Rio de Janeiro: Editora FGV, 2006.

KRACKHARDT, D.; HANSON, R.J. Informal Networks: The Company Behind the Chart. Harvard Business Review, Boston, p. 104-111, jul./aug, 1993.

LAGO JÚNIOR, M.W. Redes Sociais Informais Intra-organizacionais e os Processos de Mudanças Organizacionais: Estudo em uma Empresa de Tecnologia da Informação. 2005. 251 f. Dissertação (Mestrado Profissional em Administração) - Universidade Federal da Bahia, Salvador, 2005.

LIMA, K. K; AMARAL, C. D. Práticas de gestão do conhecimento em grupos de pesquisa da rede Instituto Fábrica do Milênio. Gestão e Produção, São Carlos, v. 15, n. 2, p. 291-305, mai./ago. 2008.

LOIOLA, E; MOURA, S. Análise de redes: uma contribuição aos estudos organizacionais. In: FISHER, T. (Org.). Gestão Contemporânea, cidades estratégias e organizações locais. Rio de Janeiro: Fundação Getúlio Vargas, 1997. p. 53-68.

MACAMBIRA, M.O. Comprometimento Organizacional e redes sociais informais: a estrutura das relações interpessoais e o vinculo com a organização. 2009. 118 f. Dissertação (Pós Graduação em Psicologia) - Programa de Pós Graduação em Psicologia, Universidade Federal da Bahia, Salvador. 2009.

MARTELETO, R. M. Análise de redes sociais: aplicação nos estudos de transferência da informação. Ciência da Informação, Brasília, v. 30, n. 1, p. 71-81, 2001. 
NONAKA. I; TAKEUCHI, H. Criação de Conhecimento na Empresa: Como as Empresas Japonesas Geram a Dinâmica da Informação. 18. ed. Rio de Janeiro: Elsevier, 1997. 358 p. Trad. Ana Beatriz Rodrigues e Priscilla Martins Celeste.

PARK, Y; KIM, S. Linkage between knowledge management and R\&D management. Journal of Knowledge Management, Bingley, v. 9, n. 4 p. 34-44, 2005.

PIMENTA, R. B. A gestão do conhecimento como fator determinante no processo de inovação do setor produtivo: um estudo de caso na Petrobras. 2006, 152 f. Dissertação (Mestrado em Engenharia de Produção) - Universidade Tecnológica Federal do Paraná, Paraná. 2006.

PROJECT MANAGEMENT INSTITUTE. Um Guia do Conjunto de Conhecimentos em Gerenciamentos de Projetos: Guia PMBOK. 4. ed. Pensilvânia, EUA: Project Management Institute, 2009. 459 p.

RODRIGUEZ Y RODRIGUEZ, M. V. Organizações que Aprendem. Rio de Janeiro: Qualitymark, 2002.559 p.

SÁ, M. F. Identificação dos atributos da gestão do conhecimento e seus impactos na gestão de contratos EPC (Engineering, Procurement, Construction) no Segmento de Petróleo \& Gás Offshore. 2008. 238 f. Dissertação (Mestrado em Sistemas de Gestão) - Universidade Federal Fluminense, Niterói. 2008.

SCOTT, J. Social Network Analysis. A Handbook. 2. ed. Thousands Oaks, California: Sage Publications, 2000. 213 p..

SILVA, A. F. Análise de redes sociais informais e o compartilhamento do conhecimento organizacional. 2010. 98 f. Dissertação (Mestrado em Administração) - Centro de Ciências Sociais e Humanas, Universidade Federal de Santa Maria, Rio Grande do Sul, 2010.

STEWART, T. A. A riqueza do conhecimento: o capital intelectual e a organização do século XXI. Rio de Janeiro: Campus, 2002. 517 p. Trad. Afonso Celso da Cunha Serra.

SUN, P. Five critical knowledge management organizational themes. Journal of Knowledge Management, Bingley, v. 14, p. 507-523, 2010.

SVEIBY, K.E. A nova riqueza das organizações: gerenciando e avaliando patrimônios de conhecimento. Rio de Janeiro: Campus, 1998. 260 p. Trad. Luiz Eucydes Trindade Frazão Filho.

VELÁSQUEZ, A.A.O;; AGUILAR,N.G. Manual Introductorio al análisis de redes sociales: Medidas de Centralidad. Redes, 2005. Disponível em: <http://revistaredes.rediris.es/webredes/talleres/Manual_ARS.pdf> Acesso em: 10 de Out. 2010. 
VERGARA, S. C. Projetos e Relatórios de Pesquisa em Administração. 12. ed. São Paulo: Atlas, 2010. $94 \mathrm{p}$.

WASSERMAN, S; FAUST, K. Social network analysis: methods and applications. Cambridge: University Press, 1994. 825 p. 